\title{
Production of Phytase by Three Thermophilic Fungi
}

\author{
R. Ranjith Kumar ${ }^{1}$, E. Rajendar Reddy ${ }^{2}$, S. Girisham ${ }^{1}$ \\ and S.M. Reddy ${ }^{3^{*}}$
}

${ }^{1}$ Department of Microbiology, Kakatiya University, Warangal

${ }^{2}$ Department of Botany, Dr. B.R. Ambedkar Open University, Hyderabad

${ }^{* 3}$ Department of Botany, Kakatiya University, Warangal

\begin{abstract}
Production of phytase by three thermophilic fungi, Thermomyces lanuginosus, Talaromyces luteus and Rhizomucor pusillus under different cultural conditions was assessed. Temperature of $45^{\circ} \mathrm{C}, \mathrm{pH}-6.0$ were optimum for phytase production by the all three fungi under investigation. Carbon and nitrogen sources for production of phytases by the three thermophilic fungi varied with the fungus. When T. lanuginosus opted for D-glucose followed by D-fructose, $T$. luteus preferred D-glucose, D-mannose and mannitol for production a phytase. On the other hand, $R$. pusillus produced maximum phytase during its growth on mannitol and maltose as carbon source. L-asparagine, L-arginine and L-asparatic acid were preferred nitrogen sources for production of phytase by $T$. lanuginosus. On the other hand T. luteus, opted for L-asparagine, Lglutamic acid and L- glycine for the activity of phytase. $R$. pusillus produced maximum phytase in medium containing L-argine, L-asparagine and L-asparatic acid.
\end{abstract}

Keywords: thermophilic fungi, phytase, temperature, $\mathrm{pH}$, carbon and nitrogen source

\section{Introduction:}

Phytase (myo-inositol hexakisphosphate hydrolases), causes release of phosphate from phytic acid, is one of the considerable importance in animal nutrition, environmental protection and biotechnology [1]. Phytic acid which is a major form of phosphorus present in the bound form in the seed based feed cannot be utilized by monogastric animals like pigs and poultry. Further, most of the phytic acid is an anti-nutrient, which complexes with protein by variety of divalent metallic cations and decreases the availability of these nutrients. Therefore, phytase has received increased

*Author for Correspondence. E-mail: profsmreddy40@gmail.com

This work is licensed under a Creative Commons Attribution-Noncommercial-Share Alike 4.0 International License. 
attention in animal feeds which upgrades feed quality by liberating phosphorus, proteins and minerals. Phytases required for commercial feed production must be thermostable with high specific activity and active over a wide range of $\mathrm{pH}$ and temperature [2]. Though mesophilic fungi have been reported to produce phytases useful in feed production [3,4], only limited information is available on production of phytases by thermophilic fungi [5]. Therefore, in the present investigations production of phytases by three thermophilic fungi under different environmental conditions was investigated and discussed in this communication

\section{Materials and Methods:}

\section{Isolation and identification of thermophilic fungi:}

An extensive and intensive survey of thermophilic fungi substrates such as coalmine soil, composting pits, birds nests, herbivors animals and soils were surveyed for the presence of thermophilic fungi. different samples were collected aseptically in a sterile polythene bags and analyses within $24 \mathrm{hrs}$.

The thermophilic fungi were isolated by the paired petriplate method as suggested by Cooney and Emerson [6]. The samples thus obtained were subjected to serial dilution and $0.1 \mathrm{ml}$ of the diluted samples was placed in a sterilized pertiplates and $15-20 \mathrm{ml}$ poured aseptically and coverd immediately covered with petriplates and allowed to cool to room temperature. the paried petriplates was dixed with cellophene tape and incubated at $40 \pm 1{ }^{\circ} \mathrm{C}$ in a incubater. the fungal colonies arising after 4-6 days were pickedup for isolation and purification. they were identified with the help of manual. they were categorized into thermophilic and thermotolerant based on the temperature requriment.

\section{Phytase production:}

Influence a different media on growth and phytase production was studied by growing three organisms in the following media

1. Yeast Extract Starch medium (A): Yeast extract 5.0g, Starch $15 \mathrm{~g}, \mathrm{MgSO}_{4} 0.5 \mathrm{~g}, \mathrm{~K}_{2} \mathrm{HPO}_{4} 0.5 \mathrm{~g}$, agar agar $20 \mathrm{~g}$ and distilled water 1 liter).

2. Yeast Extract Starch medium (B): Yeast extract 5.0g, Starch $15 \mathrm{~g}, \mathrm{MgSO}_{4} 0.5 \mathrm{~g}, \mathrm{~K}_{2} \mathrm{HPO}_{4} 0.5 \mathrm{~g}$, agar agar $20 \mathrm{~g}$ and distilled water 1 liter). $+0.1 \%$ Ca Phytate.

3. Yeast Extract Glucose medium (C): Yeast extract $5.0 \mathrm{~g}$, Glucose $15 \mathrm{~g}, \mathrm{MgSO}_{4} 0.5 \mathrm{~g}, \mathrm{~K}_{2} \mathrm{HPO}_{4}$ $0.5 \mathrm{~g}$, agar agar $20 \mathrm{~g}$ and distilled water 1 liter).

4. Yeast Extract Glucose medium (D): Yeast extract $5.0 \mathrm{~g}$, Glucose $15 \mathrm{~g}, \mathrm{MgSO}_{4} 0.5 \mathrm{~g}, \mathrm{~K}_{2} \mathrm{HPO}_{4}$ $0.5 \mathrm{~g}$, agar agar $20 \mathrm{~g}$ and distilled water 1 liter $)+0.1 \%$ Ca phytate.

5. Modified Czepek dox (E): Glucose 2.0g, L-asparagine 10.0g, $\mathrm{K}_{2} \mathrm{HPO}_{4} 1.52, \mathrm{KCl} 0.52 \mathrm{~g}$. $\mathrm{MgSO}_{4} .7 \mathrm{H}_{2} \mathrm{O}$ 0.52g, $\mathrm{CuNO}_{3}, 3 \mathrm{H}_{2} \mathrm{O}$ trace, $\mathrm{ZnSO}_{4}$ trace, Agar Agar $20 \mathrm{~g}$ and 1 liter distilled water $+0.1 \%$ Ca phytate. 
6. PSM: Phytase Screening Medium (F): $5 \mathrm{~g}$ calcium phytate; $10 \mathrm{~g}$ sucrose, $2 \mathrm{~g}\left(\mathrm{NH}_{4}\right) 2 \mathrm{SO}_{4}, 3 \mathrm{~g}$ tryptone, $2 \mathrm{~g}$ yeast extract, $0.5 \mathrm{~g} \mathrm{KCl}, 0.5 \mathrm{~g} \mathrm{MgSO}_{4}, 0.01 \mathrm{~g} \mathrm{MnSO}_{4} .5 \mathrm{H}_{2} \mathrm{O}, 0.01 \mathrm{~g} \mathrm{FeSO}, 1 \mathrm{~g}$ triton X-100.

\section{Factors influencing phytase production:}

Effect of $\mathrm{pH}$ on production of phytase was studied by adjusting the $\mathrm{pH}$ of the medium by adding $\mathrm{HCL}, \mathrm{NaOH}$ so as to get $\mathrm{pH}$ of the basal medium $\mathrm{pH} 4.0,5.0,6.0,7.0,8.0$ and 9.0. Similarly effect of incubation, temperature was studied by incubating the fungal inoculated cultures at 35 , $40,45,50$ and $55^{\circ} \mathrm{C}$. Influence of carbon and nitrogen source was studied by substituting gulcose/ potassium nitrate source separately so as to get equal amount of carbon/nitrogen concentration respectively.

Twenty eight fungal strains covering 21 thermophilic and 7 thermotolerant isolated from different thermogenic substrates according to Cooney and Emerson [6] were screened for phytase production on solidified PSM medium (Phytase Screening Medium) with calcium phytate as carbon source. However, detailed investigations were carried out on monosporic cultures of $T$. lanuginosus, T. luteus and R. pusillus isolated from birds nest, zoo wastes and coalmine soils respectively. The fungi were grown in $25 \mathrm{ml}$ medium contanied in Erlenmeyer conical flask for 8 days at $40 \pm 2{ }^{\circ} \mathrm{C}$ with initial $\mathrm{pH}$ 6.0. The experiment was carried out in triplicate. At the end of 8 days incubation period, the cultures were harvested on previously dried and weighed Whatman filter paper No. 42 . The filter papers along with mycelial mat were dried at $65-70^{\circ} \mathrm{C}$ in an oven for $48 \mathrm{hrs}$. The filter papers along with mycelial mat were cooled to room temperature in desiccator for $24 \mathrm{hrs}$ and weighed to a constant weight in an analytical balance. The mycelial mat weight was determined and an average of three values was taken as standard. The culture filtrate thus obtained was dialysed overnight against distilled water and employed as an enzyme. The other details are as described earlier [7,8,10]. The phytase activity was assayed as suggested by Wyas et al. [9].

\section{Assay of phytase:}

Phytase activity was measured in an assay mixture containing $0.5 \%$ sodium phytate and $0.2 \mathrm{M}$ sodium acetate ( $\mathrm{pH} 5.0)$ and $1.0 \mathrm{ml}$ dialyzed enzyme sample. The reaction was stopped by adding equal volume of $15 \%$ trichloroacetic acid after $30 \mathrm{~min}$ of incubation at $37{ }^{\circ} \mathrm{C}$. The liberated phosphate ions were quantified by mixing of assay mixture with $9 \mathrm{ml}$ of $0.76 \mathrm{M} \mathrm{HSO} 4,2.5 \%$ ascorbic acid and $0.06 \%$ ammonium molybdate. The reaction of after 20 min incubation at $30^{\circ} \mathrm{C}$, absorbance was measured at $820 \mathrm{~nm}$ in spectrophotometer. One phytase unit was defined as the activity that released $1 \mathrm{ml}$ of inorganic phosporus from sodium phytate per 1 minute under assay conditions.

\section{Results and discussion:}

Out of 28 species belonging to 21 thermophilic and 7 thermotolerant fungi screened for production of phytase revealed that except $H$. fuscoatra, which did not produce phytase, all other fungi found to be have potential for production of phytase. However, the degree of phytase 
production varied with the fungus. T. lanuginosus and R. pusillus proved to be good producers, while $T$. luteus was poor producer. Production of phytase by these three thermophilic fungi under different environmental conditions was investigated.

\section{i. Influence of medium}

Out of six media tried, the yeast extract starch (medium B) containing calcium phytase was most suitable for production of phytase for all three fungal species under study (fig.1). The medium F was the next preferred medium. In general medium containing phytic acid was conducive for phytase production, suggesting its adaptive nature. Similarly, Chadha et al. [10] have also recorded increased production of phytase in medium containing calcium phytate. Eight days incubation was optimum for enzyme production by all present three thermophilic fungi. Medium $\mathrm{H}$ was poor substratum for the all the three fungi understudy which may be attributed to the presence of starch.

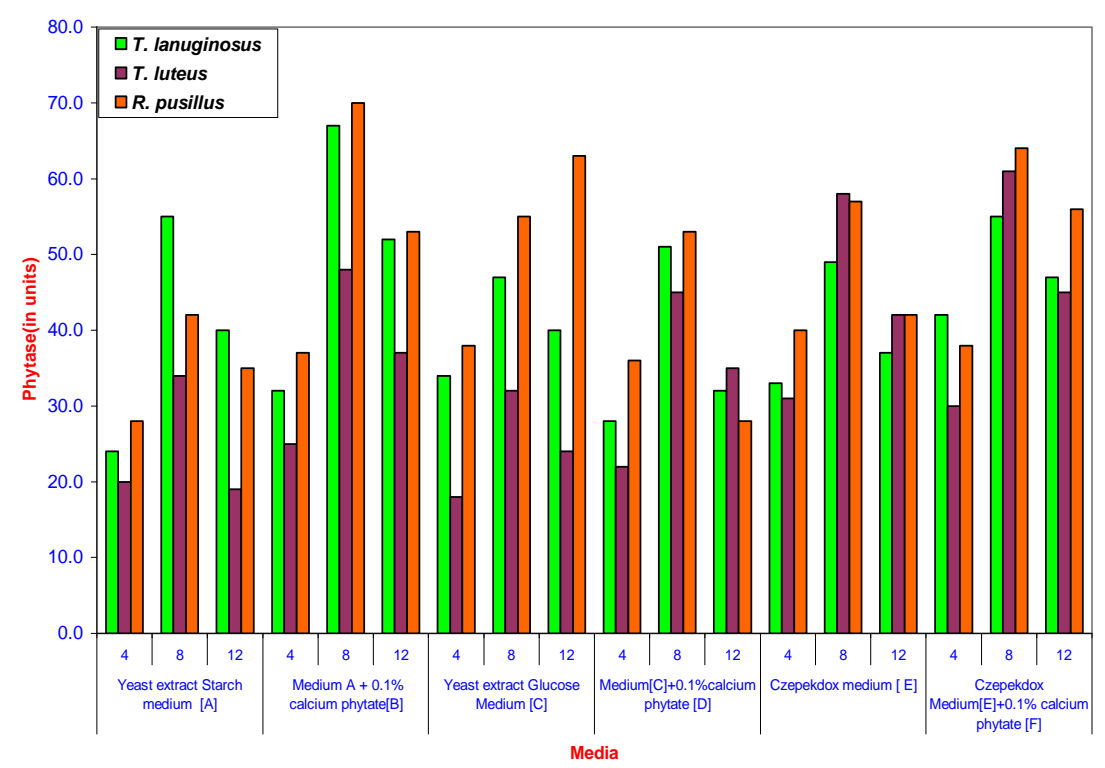

Fig.1. Effect of differnt synthetic media on phytase production by three thermophilic fiungi

\section{ii. Influence of $\mathrm{pH}$ and temperature}

pH 6.0 was optimum for production phytase for all the three species under study. Production of phytase decreased both with increase of acidity or alkalinity. T. luteus failed to grow at $\mathrm{pH} 9.0$ (table 1). Incubation temperature of $45^{\circ} \mathrm{C}$ was optimum for production of phytase by the fungi under investigation. Production of phytase decreased progressively with the increase of incubation temperature (table 2). Singh and Satyanarayana [11] also recorded maximum phytase production at $45^{\circ} \mathrm{C}$ by the fungi studied by them. 
Table 1: Effect of pH on growth and phytase*production (in 8 days) by three thermophilic fungi

\begin{tabular}{lcccccc}
\hline \multirow{2}{*}{ Name of the Organism } & \multicolumn{7}{c}{$\mathbf{p H}$} \\
\cline { 2 - 7 } & $\mathbf{4 . 0}$ & $\mathbf{5 . 0}$ & $\mathbf{6 . 0}$ & $\mathbf{7 . 0}$ & 8.0 & 9.0 \\
\hline T. lanuginosus & & & & & & \\
Dry weight $(\mu \mathrm{g} / \mathrm{ml})$ & 177.2 & 181.3 & 188.4 & 194.2 & 166.2 & 145.2 \\
$\mathrm{pH}$ & 4.7 & 5.2 & 6.3 & 5.8 & 7.6 & 7.7 \\
Phytase (in units) & 18.0 & 38.0 & 65.0 & 60.0 & 38.0 & 22.0 \\
& & & & & & \\
T. luteus & -- & 160.2 & 177.2 & 172.3 & 155.3 & -- \\
Dry weight ( $\mu \mathrm{g} / \mathrm{ml})$ & -- & 5.7 & 5.3 & 5.6 & 5.3 & -- \\
pH & -- & 36.0 & 58.0 & 48.0 & 28.0 & -- \\
Phytase (in units) & & & & & & \\
& & & & & & \\
R. pusillus & 213.7 & 247.5 & 265.8 & 233.6 & 210.2 & 155.6 \\
Dry weight ( $\mu \mathrm{g} / \mathrm{ml})$ & 4.4 & 5.3 & 6.4 & 6.3 & 7.5 & 7.6 \\
pH & 32.0 & 48.0 & 72.0 & 40.0 & 14.0 & 16.0 \\
Phytase (in units) & & &
\end{tabular}

*1 unit of phytase activity (IU) is expressed as the amount of enzyme that liberates 1 mole phosphorus per minute under assay conditions.

Table 2: Effect of temperature on growth and phytase*production (in 8 days) by three thermophilic fungi

\begin{tabular}{|c|c|c|c|c|c|c|}
\hline \multirow{2}{*}{ Name of the Organism } & \multicolumn{6}{|c|}{ Temperature $\left({ }^{\circ} \mathrm{C}\right)$} \\
\hline & 35 & 40 & 45 & 50 & 55 & 60 \\
\hline \multicolumn{7}{|l|}{ T. lanuginosus } \\
\hline Dry weight $(\mu \mathrm{g} / \mathrm{ml})$ & 176.2 & 177.3 & 189.3 & 165.3 & 153.8 & 145.2 \\
\hline $\mathrm{pH}$ & 6.4 & 6.5 & 6.3 & 6.4 & 7.6 & 7.7 \\
\hline Phytase ( in units) & 28.0 & 40.0 & 60.0 & 48.0 & 28.0 & 22.0 \\
\hline \multicolumn{7}{|l|}{ T. luteus } \\
\hline Dry weight $(\mu \mathrm{g} / \mathrm{ml})$ & 158.3 & 164.4 & 182.3 & 155.2 & 138.7 & -- \\
\hline $\mathrm{pH}$ & 6.6 & 5.7 & 5.3 & 5.8 & 5.3 & -- \\
\hline Phytase (in units) & 38.0 & 55.0 & 55.0 & 38.0 & 28.0 & -- \\
\hline \multicolumn{7}{|l|}{ R. pusillus } \\
\hline Dry weight $(\mu \mathrm{g} / \mathrm{ml})$ & 213.7 & 245.2 & 268.3 & 245.3 & 231.2 & 155.6 \\
\hline $\mathrm{pH}$ & 6.1 & 6.1 & 6.4 & 6.3 & 6.5 & 7.6 \\
\hline Phytase (in units) & 34.0 & 48.0 & 68.0 & 52.0 & 34.0 & 16.0 \\
\hline
\end{tabular}




\section{iii. Influence of carbon source:}

D-glucose followed by D-mannose was preferred carbon sources for the production of phytase by T. lanuginosus. Borges et al. [12] also recorded maximum phytase production in the presence of glucose as carbon source by M. racemosus. Enzyme secretion was minimum in medium containing succinic acid followed by D-ribose. Rest of the carbon sources induced intermediate amount of phytase production. D-glucose followed by maltose and mannitol were favorable carbon sources for the production of phytase by $\mathrm{T}$. luteus, while D-xylose and D-ribose were poor substrates (table 3). Rest of the carbon sources supported intermediate degree of phytase production by T. luteus. Mannitol followed by maltose and sucrose were the good carbon sources for production of phytase by R. pusillus. Sucrose and starch were almost equal in induction of phytase in R. pusillus. L-sorbose, D-ribose and D-galactose were least preferred carbon sources for production of phytase by R. pusillus. Vats and Benerjee [13] reported starch as a better carbon source for phytase production by Aspergillus niger .The vegetative growth of $\mathrm{T}$. lanuginosus and T. luteus was maximum in medium containing glucose, while R. pusillus preferred starch for mycelial growth.

Table 3: Influence of carbon sources on growth and Phytase*production (in 8 days)

by three thermophilic fungi

\begin{tabular}{lccccccccc}
\hline \multirow{2}{*}{ Carbon source } & \multicolumn{3}{c}{ T. lanuginosus } & \multicolumn{3}{c}{ T. luteus } & \multicolumn{3}{c}{ R. pusillus } \\
\cline { 2 - 10 } & $\begin{array}{c}\text { Dry wt } \\
(\mu \mathrm{g} / \mathrm{ml})\end{array}$ & $\mathrm{pH}$ & $\begin{array}{c}\text { phytase } \\
\text { (in units) }\end{array}$ & $\begin{array}{c}\text { Dry wt } \\
(\mu \mathrm{g} / \mathrm{ml})\end{array}$ & $\mathrm{pH}$ & $\begin{array}{c}\text { phytase } \\
(\text { in units) }\end{array}$ & $\begin{array}{c}\text { Dry wt } \\
(\mu \mathrm{g} / \mathrm{ml})\end{array}$ & $\begin{array}{c}\mathrm{pH} \\
\text { phytase } \\
\text { (in units) }\end{array}$ \\
\hline D-glucose & 198.5 & 6.4 & 68.0 & 180.7 & 6.2 & 58.0 & 245.3 & 6.2 & 42.0 \\
D-fructose & 188.4 & 6.3 & 54.0 & 171.5 & 6.4 & 44.0 & 242.8 & 6.6 & 48.0 \\
D-galactose & 175.3 & 6.4 & 48.0 & 168.4 & 6.2 & 48.0 & 234.8 & 6.4 & 36.0 \\
D-mannose & 178.3 & 6.4 & 60.0 & 178.5 & 6.3 & 56.0 & 233.8 & 5.8 & 44.0 \\
L-sorbose & 158.5 & 6.4 & 48.0 & 172.5 & 6.3 & 48.0 & 224.7 & 6.2 & 32.0 \\
D-ribose & 158.4 & 6.3 & 38.0 & 162.4 & 6.2 & 42.0 & 228.6 & 6.2 & 34.0 \\
D-xylose & 158.2 & 6.2 & 42.0 & 158.5 & 5.4 & 36.0 & 223.4 & 6.2 & 38.0 \\
Sucrose & 177.3 & 6.3 & 54.0 & 166.8 & 6.4 & 48.0 & 244.8 & 6.2 & 60.0 \\
Maltose & 165.2 & 6.2 & 58.0 & 166.4 & 6.2 & 56.0 & 242.6 & 6.1 & 66.0 \\
Lactose & 172.6 & 6.2 & 52.0 & 166.2 & 6.2 & 44.0 & 241.5 & 6.2 & 56.0 \\
Citric acid & -- & -- & -- & -- & -- & -- & 186.3 & 3.4 & 36.0 \\
Succinic acid & 134.2 & 5.2 & 22.0 & 146.8 & 4.7 & 42.0 & 191.6 & 3.8 & 32.0 \\
Mannitol & 178.4 & 6.2 & 52.0 & 178.2 & 6.0 & 52.0 & 158.3 & 6.1 & 70.0 \\
Glycerol & 158.4 & 6.2 & 48.0 & 162.4 & 6.2 & 46.0 & 243.2 & 5.8 & 48.0 \\
Starch & 168.3 & 6.6 & 52.0 & 162.8 & 6.2 & 44.0 & 247.9 & 6.3 & 60.0 \\
\hline
\end{tabular}

*1 unit of phytase activity (IU) is expressed as amount of enzyme that liberates 1 mole phosphorus per minute under assay conditions 


\section{iv. Influence of nitrogen source:}

L-asparagine induced maximum phytase in T. lanuginosus, while L-arginine and L-aspartic acid were next preferred nitrogen source for the production of phytase. L-methionine and L-histidine were responsible for poor growth of $T$. lanuginosus. Amine form of nitrogen was superior source of nitrogen over the acid form for all the three fungi under investigation. Ammonium compounds were inferior source of nitrogen for induction of phytase in all the three fungi understudy. Lasparagine followed by L-glutamic acid and L-glycine were responsible for maximum production of phytase by T. luteus, while ammonium chloride, L-methionine and ammonium nitrate were poor nitrogen sources. Rest of the nitrogen sources supported intermediate amount of phytase production by T. luteus. $R$. pusillus produced maximum phytase in medium containing L-arginine, L-asparagine and L-aspartic acid, while ammonium salts were poor nitrogen sources for phytase production (table 4). Ashes and Duvnjak [14] recorded significant influence of nitrogen source on phytase production by the fungi studied by them. Response of all the three fungi was uniform towards ammonium nitrate. Tyrosine was a good source of nitrogen for T. luteus and R. pusillus. On the other hand Aspergillus niger produced maximum phytase on peptone followed by ammonium nitrate and ammonium sulphate [15]. The vegetative growth of $T$. lanuginosus and $T$. luteus was maximum in medium containing L-asparagine, while $R$. pusillus recorded maximum growth in medium containing L-arginine as a nitrogen source. Eight days of incubation period was optimum for production of phytase on all the nitrogen sources tried. The $\mathrm{pH}$ changes were minimum in all the nitrogen sources tried and the final $\mathrm{pH}$ was near neutral.

The present studies on thermophilic fungi confirmed the observations of $[3,15,16]$ on Myceliophthora thermophila, Aspergillus fumigates and Mucor racemosus respectively.

Table 4: Influence of nitrogen sources on growth and Phytase *production (in 8 days)

by three thermophilic fungi

\begin{tabular}{lccccccccc}
\hline & \multicolumn{3}{c}{ T. lanuginosus } & \multicolumn{3}{c}{ T. luteus } & \multicolumn{3}{c}{$R$. pusillus } \\
\cline { 2 - 10 } Nitrogen source & $\begin{array}{c}\text { Dry wt } \\
(\mu \mathrm{g} / \mathrm{ml})\end{array}$ & $\mathrm{pH}$ & $\begin{array}{c}\text { phytase } \\
\text { (in units) }\end{array}$ & $\begin{array}{c}\text { Dry wt } \\
(\mu \mathrm{g} / \mathrm{ml})\end{array}$ & $\mathrm{pH}$ & $\begin{array}{c}\text { phytase } \\
\text { (in units) }\end{array}$ & $\begin{array}{c}\text { Dry wt } \\
(\mu \mathrm{g} / \mathrm{ml})\end{array}$ & $\begin{array}{c}\mathrm{pH} \\
\text { phytase } \\
\text { (in units) }\end{array}$ \\
\hline Ammonium chloride & 156.2 & 5.6 & 24.0 & 148.5 & 5.8 & 24.0 & 212.6 & 6.2 & 26.0 \\
Ammonium nitrate & 154.2 & 5.5 & 30.0 & 155.8 & 5.8 & 30.0 & 226.8 & 5.6 & 30.0 \\
Ammonium sulphate & 155.2 & 5.5 & 28.0 & 152.6 & 5.8 & 38.0 & 234.6 & 5.8 & 30.0 \\
L-arginine & 187.3 & 5.7 & 54.0 & 174.8 & 5.7 & 48.0 & 265.8 & 6.6 & 72.0 \\
L-asparagine & 189.4 & 6.4 & 60.0 & 178.3 & 6.4 & 58.0 & 255.7 & 6.4 & 64.0 \\
L-aspartic acid & 168.5 & 5.8 & 42.0 & 162.4 & 6.4 & 36.0 & 245.6 & 6.3 & 52.0 \\
L-glutamine & 167.3 & 6.2 & 40.0 & 154.3 & 5.8 & 44.0 & 236.4 & 5.8 & 36.0 \\
L-glutamic acid & 175.3 & 6.0 & 30.0 & 172.4 & 6.2 & 52.0 & 221.8 & 5.5 & 34.0 \\
L-Glycine & 183.7 & 6.2 & 38.0 & 165.4 & 5.9 & 48.0 & 211.8 & 5.8 & 48.0
\end{tabular}




$\begin{array}{llllllllll}\text { L-methionine } & 155.2 & 5.5 & 24.0 & 154.2 & 5.4 & 24.0 & 202.4 & 5.6 & 38.0 \\ \text { L-histidine } & 147.3 & 5.8 & 28.0 & 164.2 & 6.4 & 38.0 & 212.4 & 6.3 & 32.0 \\ \text { L-lysine } & 158.3 & 6.2 & 38.0 & 162.4 & 6.2 & 32.0 & 232.4 & 6.2 & 38.0 \\ \text { L-tryptophan } & 159.3 & 6.0 & 38.0 & 144.8 & 5.8 & 38.0 & 241.2 & 6.3 & 48.0 \\ \text { L-tyrosine } & 166.4 & 5.8 & 28.0 & 155.8 & 6.2 & 44.0 & 227.3 & 5.8 & 41.0 \\ \text { Yeast extract } & 182.5 & 6.2 & 54.0 & 177.3 & 6.4 & 52.0 & 254.3 & 6.4 & 48.0\end{array}$

*1 unit of phytase activity (IU) is expressed as amount of enzyme that liberates 1 mole phosphorus per minute under assay conditions.

\section{Conclusion:}

Present studies R. pusillus is a versalite fungus and produces phytase in good amount. its ability to grow and produce phytase a pure synthetic medium is a desirable quality and can be exploited economically in a large scale fermetation. Further, the $\mathrm{pH}$ changes were also minimum with good amount mycelial growth is an added advantage. other two fungi through produced phytase their specificity to substrates and $\mathrm{pH}$ changes during their growth submerged conditions is an disadvantage. more in dephth studies under varied condition and catatytic properties of phytase are needed.

Acknowledgement: Authors express their gratitude to the Head, Department of Microbilogy, Kakatiya University, Warangal and UGC, New Delhi for providing laboratory facilities and financial assistance respectively.

Conflict of interest statement: Authors have no conflicts of interest to declare.

\section{References:}

1. Lei X.G. and Stahl C.H., 2001, "Biotechnological development of effective phytases for mineral nutrition and environmental protection”, Appl. Microbiol. Biotechnol., 57, pp.474- 481.

2. Radcliffe, J.S., Zhang, Z. and Kornegay, E.T., 1998, "The effect of microbial phytase, citric acid and their interaction in a corn soybean meal based diet for Weaning pigs", J.Animal Sci., 76,pp.1880-1886.

3. Liu, O., Huang, Q.Q., Lei, X.G. and Hao, Q., 2004, "Crystallographic snapshots of Aspergillus fumigatus phytase, revealing its enzymatic dynamics”. Structure., 12,pp. 1575-1583.

4. Ramachandran, S., Roopesh, K., Nampoothiri, K.M., Szakacs, G. and Pandey, A., 2005, "Mixed substrate fermentation for the production of phytase by Rhizopus spp. using oilcakes as substrates", Process Biochem., 40,pp.1749-1754.

5. Nampoothiri, K.M., Tomes, G.J., Roopesh, K., Szakacs, G., Nagy, V., Soccol, C. R. and Pandey, A, 2004, "Thermostable phytase production by Thermoascus aurantiacus in submerged fermentation", Appl. Biochem. Biotechnol., 118, pp. 205-214.

6. Cooney, D.C. and Emerson, R., 1964, "Thermophilic fungi: An account of their Biology, Activities and Classification”, San Fransisco; London, W.H. Freeman\& Co., pp-188. 
7. Pandey, A., Szakacs, G., Soccol, C.R., Rodriguez-Leon, J.A. and Soccol, V.T., 2001, "Production, purification and properties of microbial phytases", Bioresour. Technol.,77,pp. 203-214

8. Bogar, B., Szakacs, G., Linden, J.C., Pandey, A. and Tengerdy, R.P., 2003, "Optimization of phytase production by solid substrate fermentation”, J. Ind. Microbiol. Biotechnol.,30,pp. 183189.

9. Wyas, M., Brugger, R., Konenberger, A., Remy, R., Fimbel, R., Oesterhelt, G., Lehmann. and Van loon, A.P.G.M., 1999,"Biochemical characterization of fungal phytase(myo-inositol hexobisphospate Phospohydrolases) catalyte properties", Applied and Environ Microbiol., 65,pp. 367-373.

10. Chadha, B.S., Gulati, H., Minhas, M., Saini, H.S. and Singh, N., 2004,"Phytase production by the thermophilic fungus Rhizomucor pusillus”, World. J. Microbiol. Biotechnol., 20, pp. 105- 109.

11. Singh, B. and Satyanarayana, T., 2006,"Marked enhancement in phytase production by a thermophilic mould Sporotrichum thermophile using statistical designs in a cost-effective cane molasses medium". J. Appl. Microbiol., 5,pp. 344-352.

12. Borges, K.B,, de Souza, W.B., Rosa, D., Monica, T.P., Tallarico, P., Pierina, S.B. and Isidro G.C., 2009, "Stereoselective biotransformations using fungi as biocatalysts", Tetrahedron: Asymmetry., 20,pp. 385397.

13. Vats, P. and Banerjee, U.C., 2002, "Studies on the production of phytase by newly isolated strain of Aspergillus niger var teigham obtained from rotten wood logs". Process.Biochem.,38,pp.211-217.

14. Ashes, S. and Duvnjak, Z., 1995, "Production of phytase during solid state fermentation using Aspergillus ficcum NRRL 3135 in canola meal”, Bioresource Technol., 53,pp. 7-12.

15. Mitchell, D.B., Vogel, K., Weimann, B.J., Pasamontes, L. and Van Loon, A.P.,1997, "The phytase subfamily of histidine acid phosphatases: isolation of genes for two novel phytases from the fungi Aspergillus terreus and Myceliophthora thermophila", Microbiology., 143, pp.245-252.

16. Roopesh, K., Ramachandran, S., Nampoothiri, K.M., Szakacs, G. and Pandey, A., 2006, "Comparison of phytase production on wheat bran and oilcakes in solid-state fermentation by Mucor racemosus", Bioresour. Technol., 97, pp. 506-511. 